\title{
Treatment of Parkinson's Disease through Personalized Medicine and Induced Pluripotent Stem Cells
}

\author{
Theo Stoddard-Bennett ${ }^{1,2, *}$ and Renee Reijo Pera ${ }^{1,2}$ \\ 1 Department of Cell Biology and Neurosciences, Montana State University, Bozeman, MT 59717, USA; \\ renee.reijopera@montana.edu \\ 2 Department of Chemistry and Biochemistry, Montana State University, Bozeman, MT 59717, USA \\ * Correspondence: theo.n.bennett@gmail.com; Tel.: +1-406-599-9407
}

Received: 4 December 2018; Accepted: 30 December 2018; Published: 7 January 2019

\begin{abstract}
Parkinson's Disease (PD) is an intractable disease resulting in localized neurodegeneration of dopaminergic neurons of the substantia nigra pars compacta. Many current therapies of PD can only address the symptoms and not the underlying neurodegeneration of PD. To better understand the pathophysiological condition, researchers continue to seek models that mirror PD's phenotypic manifestations as closely as possible. Recent advances in the field of cellular reprogramming and personalized medicine now allow for previously unattainable cell therapies and patient-specific modeling of PD using induced pluripotent stem cells (iPSCs). iPSCs can be selectively differentiated into a dopaminergic neuron fate naturally susceptible to neurodegeneration. In iPSC models, unlike other artificially-induced models, endogenous cellular machinery and transcriptional feedback are preserved, a fundamental step in accurately modeling this genetically complex disease. In addition to accurately modeling PD, iPSC lines can also be established with specific genetic risk factors to assess genetic sub-populations' differing response to treatment. iPS cell lines can then be genetically corrected and subsequently transplanted back into the patient in hopes of re-establishing function. Current techniques focus on iPSCs because they are patient-specific, thereby reducing the risk of immune rejection. The year 2018 marked history as the year that the first human trial for PD iPSC transplantation began in Japan. This form of cell therapy has shown promising results in other model organisms and is currently one of our best options in slowing or even halting the progression of PD. Here, we examine the genetic contributions that have reshaped our understanding of PD, as well as the advantages and applications of iPSCs for modeling disease and personalized therapies.
\end{abstract}

Keywords: induced pluripotent stem cells; Parkinson's disease; alpha-synuclein; cell- and tissue-based therapy; disease modeling; dopaminergic neurons

\section{Introduction}

Neurodegenerative diseases continue to pose increasing physical and financial burdens in an aging world, despite centuries of study. These disorders include Parkinson's disease (PD), Alzheimer's disease (AD), amyotrophic lateral sclerosis (ALS), Batten disease, and Huntington's disease, among others. Since their discovery, neurodegenerative diseases have been clinically identified through post-mortem and physical examination. Formation of protein aggregates, localized neuronal death, and progressive symptoms are all typical of neurodegeneration; however, our knowledge of the pathogenesis and etiology underlying these disorders has been rebuilt due to recent advances in the field of genetics. Spurred by regenerative medicine, research in personalized medicine continues to search for underlying pathological mechanisms and novel therapies to halt or even slow the progression 
of these crippling diseases using stem cells (Figure 1). With advances in cellular reprogramming, iPSCs provide the greatest potential for cell therapy of localized neurodegeneration as found in PD. Due to iPSCs patient-specificity, the likelihood of an immune response after transplantation can be significantly reduced.

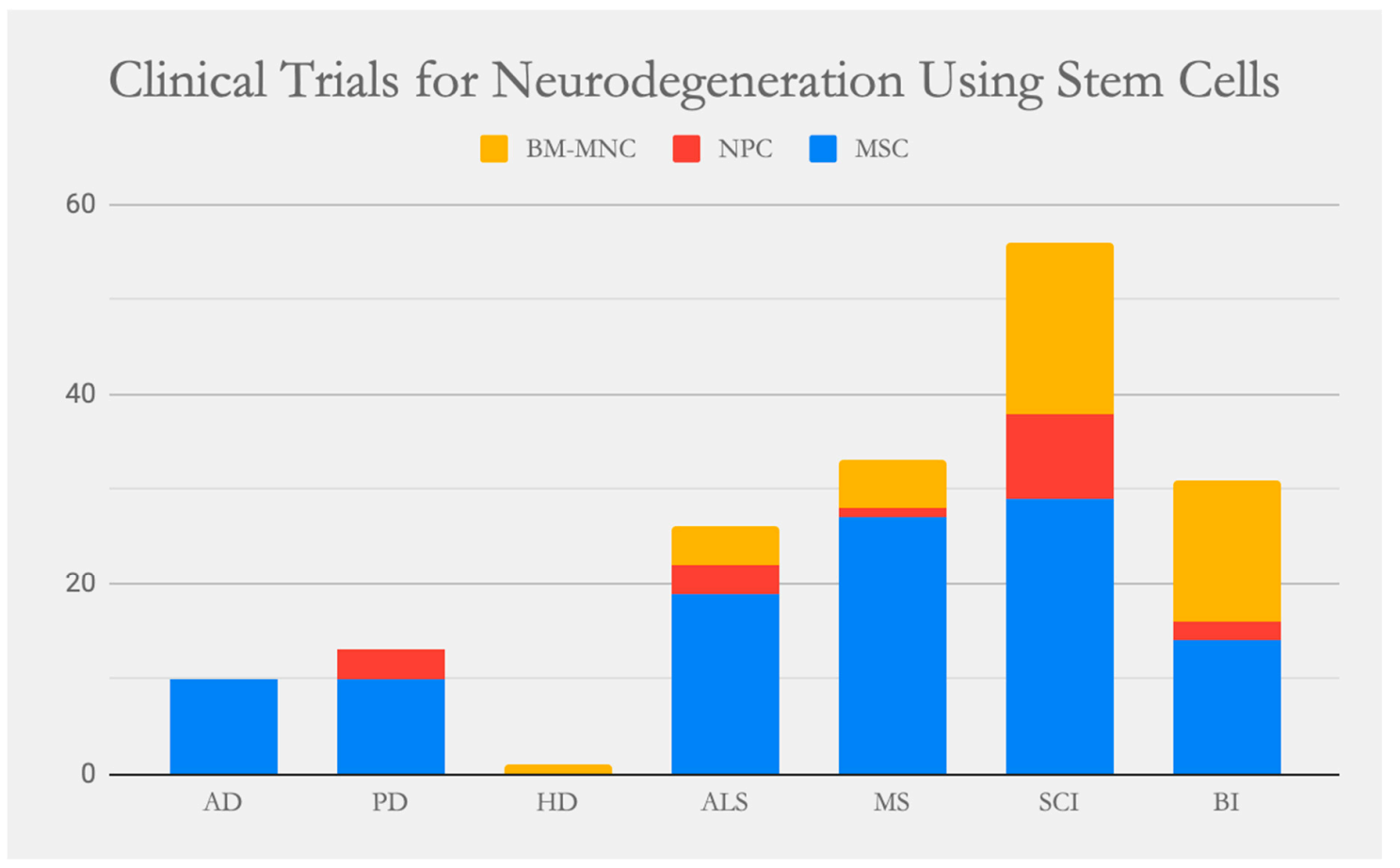

Figure 1. Clinical trials that have been or are being conducted worldwide to treat neurodegeneration using stem cells. To date, 170 clinical trials have employed mesenchymal stem cells (MSC), neural progenitor stem cells (NPC) and bone marrow-derived mononuclear cells (BM-MNC) in attempts to alleviate the neurodegeneration of Alzheimer's disease (AD), Parkinson's disease (PD), Huntington's disease (HD), amyotrophic lateral sclerosis (ALS), multiple sclerosis (MS), spinal cord injury (SCI) and brain ischemia (BI). The data was collected from https:/ / clinicaltrials.gov on 21 December 2018.

\section{Pathology of Parkinson's Disease}

$\mathrm{PD}$ is the second most common neurodegenerative disease, debilitating $1 \%$ of the population over the last 60 years [1]. As such, it poses a special problem in aging societies [2,3]. Though many neuronal networks are affected by PD, it is the dopaminergic neurons (DAn) of the substantia nigra pars compacta (SNpc) [4-6] and cholinergic nucleus Basalis of Meynert that are most acutely lost [7]. The localized cell death of the SNpc results in disruption of the basal ganglia's motor control network, causing the characteristic motor symptoms of PD—bradykinesia, tremors, rigidity and other changes in speech and gait. PD's histopathology is marked by the presence of Lewy bodies and Lewy neurites that contain misfolded alpha-synuclein [8]. Found within Lewy bodies and Lewy neurites, the expression of alpha-synuclein has been attributed to PD's pathogenesis. The exact function of unaffected alpha-synuclein, thought to also assist in vesicle turnover and synaptic release, remains unknown [9]. However, one study suggests that alpha-synuclein, when properly folded into its tetramer, exhibits protective properties and slows Lewy body formation and aggregation [10]. Lewy body formation typically begins in the SNpc, but a progressive spread to other structures in the brain has also been documented [11]. The role of alpha-synuclein has increased attention towards other non-motor symptoms of PD which include autonomic dysfunction, sleep disorders and neuropsychiatric symptoms (depression, psychosis, hallucinations) [12]. Many etiological questions remain. Although motor symptoms are only documented in $80 \%$ of revealed post-mortem alpha-synucleinopathy [13], these motor symptoms persist as a hallmark of clinical diagnosis. Here we examine the discoveries 
leading to our current understanding of $\mathrm{PD}$, as well as propose iPSC transplantation as one of the most viable forms of disease-modifying therapy for PD.

\section{Major Genetic Discoveries in Parkinson's Research}

In 2018, at least 5 major autosomal dominant genes, 5 autosomal recessive or $\mathrm{X}$-linked factors and 11 monogenetic mutations for other disorders that present with Parkinsonian-like symptoms have been identified [14]. The most notable of these are mutations and polymorphisms of Leucine-rich repeat kinase 2 (LRRK2), a gene that plays a role in neuronal survival [15], and the SNCA gene which encode for a protein called alpha-synuclein (Table 1) [16]. However, while strongly supported by a large body of statistical evidence [17], the effect of all known genetic mutations and risk-enhancing polymorphisms combined only explain a portion of the genetic risk of disease. The heterogeneity of genetic factors only serves to highlight the complex interplay in neurodegeneration. These mutations may not be causal; they can, however, elevate risk 2- to 3-fold [18]. Patient-specific cell lines and powerful gene-editing tools now allow the study of these mutations in isolation. Current advances in genetic probing will only allow for sharper analysis in genetic counseling, enhanced understanding of PD's progression and ultimately patient-specific treatments.

In 1997, a novel, rare mutation was identified in the SNCA gene that coded for a relatively unknown protein called alpha-synuclein [16]. The missense mutation (A53T) resulted in autosomal dominant PD inheritance that could be tracked through the hereditary line with almost full penetrance. Additionally, five other missense mutations to the SNCA gene, A30P, E46K, H50Q, G51D and G209A have also been reported with varying ages of PD onset [14]. More common duplications and triplications of the SNCA gene were later linked in a family known as the Iowa Kindred. The double and triple doses resulted in overexpression of natural alpha-synuclein and pathological PD [19].

In 2002, Funayma et al. reported that a region of chromosome 12 was found to be linked to PD inheritance in a Japanese family $[20,21]$. Two years later, the gene of interest was identified as LRRK2 [22]. Mutations to LRRK2 are by far the most common cause of genetic influence on $\mathrm{PD}[21,23]$. Many other mutations of $L R R K 2$ have been reported, but few remain statistically significant. Inheritance follows an autosomal dominant pattern with an age-related penetrance ranging from $28 \%$ at age 59 to $74 \%$ at 79 [24]. LRRK2 mutations comprise $4 \%$ of reported familial PD, and most cases exhibit pathology indistinguishable from sporadic PD with both Lewy body formation and DAn death [22,24]. PD from LRRK2 heredity follows the typical pattern with an onset later in life and excellent response to levodopa (L-Dopa), a precursor to dopamine that can pass the blood-brain barrier, whereas SNCA inheritance is earlier-onset. Curiously, patients with LRRK2 PD experience less severe motor symptoms associated with the frequency of falls and progression of dyskinesia [24]. Studies in cellular models that harbor these mutations show increased kinase activity resulting in neuro-oxidative stress and toxicity $[25,26]$. Although the protein is multifunctional, LRRK2 knock-downs inhibit differentiation from neural progenitors to DAns and increase cell death [15]. These findings suggest LRRK2's facilitation in cell survival and differentiation in the ventral midbrain.

Genetic loci have also been identified in familial PD that follow autosomal recessive inheritance. Two genes, phosphate and tensin homolog-induced putative kinase 1 (PINK1) and Daisuke-Junko-1 (DJ-1), are of special interest because they are involved in neuronal survival under cellular stress (Table 1). In cases of homozygosity, both PINK1 and DJ-1 mutations result in very early onset in the 30 's, low response to L-Dopa treatment and slow disease progression [27,28]. Additionally, an astute clinical observation of the comorbidity between Gaucher disease (GD) and PD led researchers to examine other proteins with suspect. GD is an autosomal recessive disease resulting from homozygous mutations to housekeeping glucocerebrosidase gene (GBA) (Table 1). GBA, a lysosomal enzyme of the CNS, is thought to also have a role in protein aggregation in PD when mutated [29]. The symptoms and pathophysiology closely follow the progression of PD, even L-Dopa therapy is effective for treating GBA mutation. Post-mortem analysis also reveals Lewy body and Lewy neurite formation. GBA mutations do not natively aggregate as cleanly in PD inheritance and only display $29.7 \%$ penetrance in populations 
over the age of 80 [29]. GBA mutations have been proven in 2009 to be the most common genetic risk factor for PD so far-present in 3-7\% of idiopathic PD cases [30]. Technological advances combined with ever-increasing sample sizes and collaboration will hopefully uncover more sources of genetic and epigenetic influence. A summary of the genes discussed above are summarized in Table 1.

Table 1. Major Familial Forms and Genetic Factors of Parkinson's Disease.

\begin{tabular}{|c|c|c|c|c|}
\hline PD Inheritance & $\begin{array}{c}\text { Disease, } \\
\text { (Mutations) }\end{array}$ & Gene, Location & Gene Function & Phenotype \\
\hline \multirow[t]{2}{*}{ Autosomal dominant } & $\begin{array}{c}\text { PARK-SNCA, } \\
\text { (A53T, duplication, } \\
\text { triplication) }\end{array}$ & $S N C A, 4 \mathrm{q} 22-1$ & $\begin{array}{l}\text { The SNCA gene codes for the alpha-synuclein } \\
\text { protein that is widely expressed in presynaptic } \\
\text { terminals of neurons. Alpha-synuclein } \\
\text { maintains the production of vesicles involved } \\
\text { in neuronal communication. Alpha-synuclein } \\
\text { is also thought to play a role in dopamine } \\
\text { expression of voluntary and involuntary } \\
\text { movement pathways. }\end{array}$ & $\begin{array}{l}\text { Early-onset PD. } \\
\text { Neurodegeneration within } \\
\text { the SNpc and Lewy Body } \\
\text { formation throughout } \\
\text { the brain. }\end{array}$ \\
\hline & $\begin{array}{c}\text { PARK-LRRK2, } \\
(\text { G0219s, R1441C) }\end{array}$ & LRRK2, 12q12 & $\begin{array}{l}\text { Encodes the leucine rich repeat kinase } 2 \\
\text { protein, expressed in the cytoplasm and } \\
\text { mitochondrial membranes of neurons. } \\
\text { LRRK2 is heavily involved in the } \\
\text { ubiquitination of molecules, leading to their } \\
\text { degradation. The precise function in PD is not } \\
\text { known, but it is thought to coordinate neuronal } \\
\text { survival and differentiation in the midbrain. }\end{array}$ & $\begin{array}{l}\text { Late-onset PD with mixed } \\
\text { neuropathology. Some cases } \\
\text { present with Lewy Body } \\
\text { formation and DAn death in } \\
\text { the SN, others without Lewy } \\
\text { Body formation. }\end{array}$ \\
\hline \multirow[t]{2}{*}{ Autosomal recessive } & $\begin{array}{c}\text { PARK-DJ1, } \\
(Q 456 X, V 170 G)\end{array}$ & $D J-1,1 \mathrm{p} 36.23$ & $\begin{array}{l}\text { Encodes the protein DJ-1, found in the brain } \\
\text { and other tissues throughout the body. DJ-1 is a } \\
\text { multi-functional protein with roles involved in } \\
\text { the prevention of alpha-synuclein aggregation, } \\
\text { neuronal protection under conditions of } \\
\text { oxidative stress, transcriptional regulation and } \\
\text { prevention of metal-induced cytotoxicity. All or } \\
\text { some of these functions may be involved in } \\
\text { some types of early PD formation. }\end{array}$ & $\begin{array}{l}\text { Conclusive data has not } \\
\text { been reported. }\end{array}$ \\
\hline & $\begin{array}{l}\text { PARK-PINK1, (exon } \\
7 \text { deletion) }\end{array}$ & PINK1, 1p36.12 & $\begin{array}{l}\text { Codes for the protein PTEN-induced putative } \\
\text { kinase 1, located within mitochondria. PINK1 } \\
\text { exhibits a protective function of mitochondria } \\
\text { during cellular stress by causing the parkin } \\
\text { protein to bind to depolarized mitochondria } \\
\text { and induce autophagy. }\end{array}$ & $\begin{array}{l}\text { Early-onset PD complete } \\
\text { with Lewy Body formation } \\
\text { and acute DAn loss in } \\
\text { the SNpc. }\end{array}$ \\
\hline Genetic risk factor & $\begin{array}{l}\text { Gaucher Disease } \\
(L 444 P, N 370 S)\end{array}$ & $G B A, 1 \mathrm{q} 22$ & $\begin{array}{l}\text { Codes for an enzyme active in lysosomes and } \\
\text { cellular membranes. Beta-glucocerebrosidase is } \\
\text { a housekeeping enzyme hydrolyzes the } \\
\text { beta-glucosidic linkage of glucocerebroside } \\
\text { into glucose and ceramide. Mutation causes } \\
\text { glucocerebroside buildup in macrophages. }\end{array}$ & $\begin{array}{l}\text { Severe neurological } \\
\text { complications in addition to } \\
\text { liver failure, bone lesions } \\
\text { and low blood cell counts. }\end{array}$ \\
\hline
\end{tabular}

\section{Tailored Therapies of Genetic Parkinson's Disease}

The pathology behind PD involves the dysfunction of multiple systems and neurotransmitters that lead to similar symptoms. However, the highly variable and clustered patient responses to L-Dopa treatment suggests that different biochemical mechanisms of degeneration may necessitate differing treatment approaches [31,32]. These differences include variation in motor response, dyskinesias, psychotic episodes, sleep disturbances and visual hallucinations. The approach of personalized medicine offers more effective clinical therapies and added benefit for patients living with specific subsets of PD. Personalized medicine is widely conflated with precision medicine when discussing medical interventions and we will use both interchangeably to consider targeted therapies for a given subpopulation of PD patients, as well as holistically approaching their condition.

The influence of specific genetic factors could explain some of the variability in individual drug response. Genetic differences play a large role in the metabolic pathway of drug uptake which could affect response to treatments [33,34]. Though much of the heritability of PD has yet to be explained, the field of pharmacogenomics attempts to examine the effects of genetics on drug mechanics - specifically the interplay of dopamine transporters, receptors and enzymes critical for dopamine processing for PD. Patients with familial LRRK2 PD could be treated with LRRK2 inhibitors and pharmaceutical companies have begun clinical trials earlier this year (ID: NCT03710707) [35,36]. Conversely, specific drug regimens carry added risk for specific genotypes. Those harboring a polymorphism of the dopamine active transporter 1 gene (DAT1), a gene involved in the reuptake of 
dopamine in chemical synapses, are 2.5 times more likely to develop dyskinesias when treated with L-Dopa while a different point mutation of DAT1 was shown to increase the risk of hallucination when treated with dopaminergic drugs [34,37]. Genetic factors are also influenced by gender for treatment. Dopamine receptor D2 (DRD2), a dopaminergic receptor subtype, polymorphisms protect L-Dopa induced dyskinesias in men but do not has protective effects for women [38]. Genetic differences can also be influenced by epigenetic factors as well. In the future, clinicians may also personalize treatment modalities based on the physiological progression of the individual as opposed to the severity of symptoms. Researchers are developing alpha-synuclein tracers to examine the localization and severity of alpha-synuclein formation in vivo, however, this technology is not currently available [39-41]. Though the implementation of personalized medicine based on specific subtype offers many benefits for patients, treatment modalities may require constant modification due to the progressive and dynamic nature of PD.

Ultimately, personalized treatment of PD embodies the holistic span of age, lifestyle, genotype, personality and other concurrent illnesses. This strategy is relatively new and ideally rests on a multidisciplinary team to ensure all the patients' specific needs are considered before pursuing a given treatment plan. Patients are assessed by disease sub-group but, above all, treatments should be tailored to the individual. Genotype is not the only factor in prescribing treatments. Ropinirole and other dopamine agonists work for some patients, but their increased risk of impulse control disorders warrants caution if the individual already has impulsive tendencies [42]. Because PD afflicts an aging population, bone health and fall risk should be weighed with motor treatments and supplemented with vitamin D2 and bisphosphonates. For patients with cardiovascular issues, quetiapine and other antipsychotics that prolong the QTc interval should be avoided. Similarly, those with vascular impairments in the brain must have their homocysteine levels regulated when undergoing high dose L-Dopa treatment. Endocrine issues may also affect treatment plans. Those with hyperthyroidism or low body weight may receive lower levels of L-Dopa treatment. With new information and conflicting studies, best-practice guidelines continue to be altered and so no definite methods of therapy can be provided [34]. This places the onus on researchers to provide more nuanced insight using model systems that better represent PD pathology in order to deliver better care.

\section{Pluripotent Stem Cells}

To better understand Parkinson's disease, researchers have sought models that mirror PD's phenotypic manifestations as closely as possible. To date, researchers have used model organisms (yeast, mice, Drosophila and non-human primates) in three ways. First, organisms were subjected to direct injections into the central nervous system of 6-hydroxydopamine (6-OHDA) and 1-methyl-4-phenyl-1,2,5,6-tetrahydropyridine (MPTP) to mimic DAn cell death in the SNpc through oxidative stress. While helpful in examining the effects of blocking dopamine expression, this artificially induced model fails to reconstruct the underlying neuropathology of highly-sensitive DAn and typical formation of Lewy neurites and Lewy bodies. Second, overexpression of the human risk factors, such as the SNCA gene, in mouse models has shown age-dependent DAn degeneration similar to the human pathological phenotype $[8,43,44]$. These results support a causal role for alpha-synuclein in PD progression but currently, lack clinical application. Finally, human embryonic stem cells (hESC) and induced pluripotent stem cells (iPSC) have been grafted into model organisms in an existing PD state. This procedure has shown mixed but promising results [45-51].

Both hESCs and iPSCs possess unique qualities that make them ideal candidates for studying the development of PD [52]. Stem cells can be tailored to differentiate into a host of cell fates, including DAn of the SNpc that model PD on a cellular level $[53,54]$. Induced stem cells are also patient-specific, opening a window to the individual contribution of mutation and polymorphism risk factors on PD in a phenotypically similar state. DAn longevity can also be compared with other iPSC neurons such as cortical and olfactory neurons to probe the hypersensitivity of DAns specifically in the SNpc. Furthermore, the advent of TALEN, CRIPSR and other genetic reprogramming technologies have been 
applied to patient lines of iPSCs and extensively reviewed $[55,56]$. Corrected mutation lines can then be examined. Deriving a high percentage of fully functional, mature DAn of the ventral midbrain can be quite challenging and costly to scale up. The technical, in addition to ethical, obstacles of iPSC treatment may limit the feasibility of transplanting reprogrammed stem cells, but this opportunity in PD treatment is unprecedented. The first human clinical trial to transplant DAns from an iPSC source begins this year in Japan (ID: UMIN000033564) [57].

\section{6. iPSCs as Disease Model for Parkinson's Disease}

The contribution of pharmacogenomics has been heightened through the use of patient-specific iPSC lines and genetic engineering technology to manipulate them. Ever since Yamanaka's discovery in 2007 that a handful of transcription factors can reprogram cellular differentiation, iPSCs have been utilized extensively in the study of neurodegenerative disease to direct patient-specific cell fate [58,59]. While still limited in scope, iPSCs are currently the most robust and phenotypically similar model for PD [60]. Mutations of consequence can now be captured in iPSC lines and directed by small molecules to a DAn fate in PD models-all within a dish. Displayed openly, the real-time cellular effects of mutation can be physically observed and studied in tandem with control lines to limit genetic background effects of the affected individual; similarly, effects of oxidative stress common to PD can also be quantified with broad clinical applications for drug screening without human side-effects. Not surprisingly, it remains difficult to physically confirm the mechanisms of neurodegeneration and neuroprotection implicated by iPSC research as patients' neurons are hidden deep within the brain. These effects similarly cannot be perfectly translated into the cellular environment of PD due to some epigenetic effects of aging eliminated in reprogramming protocols.

Differentiation of iPSCs to midbrain DAns begins with the initial dedifferentiation. In the last 10 years, thousands of iPSC lines have been generated by overexpressing certain transcriptional factors in somatic cells to bring them back to a pluripotent state. Those methods have been extensively reviewed [55,56]. Current methods of reprogramming employ episomes, viruses and synthetic mRNA to upregulate expression of the transcription factors without genomic integration that leads to tumorigenesis [61-63]. Dedifferentiation often results in mutation and, consequently, not all iPSC lines are of equal quality. Though iPSC reprogramming theoretically results in a clonal copy of the genome, sequencing entire genomes of iPSCs have revealed an average of 6 de novo mutations during reprogramming in coding regions [64]. Extensive quality controls are in place to measure the quality of iPSC lines such as expression of neural markers, transcriptome analysis of iPSC lines with available data of hESC expression as well as bioinformatics tests like Pluritest [65]. These safeguards are critical if clinicians wish to implement iPSCs further in personalized medicine.

Differentiation from pluripotent stem cells to mature DAns of the midbrain mimics a specific pathway in embryological development. Initially dopaminergic neurons of the SNpc were originally thought to have derived from neuroepithelial cells like other cortical neurons, but in fact, they are similar to the spinal cord, derived from the ventral floor plate of the neural tube [66]. The embryologic origin was confirmed by expression of other floor-plate markers such as Lmx1a and FoxA2 $[67,68]$. Differentiation protocols using small molecules and neurotrophic factors mimic in vivo neural floor-plate patterning by activating the sonic hedgehog $(\mathrm{SHH})$ pathway, inhibition of SMAD and addition of FGF8 [69,70]. Differentiation through transfecting transcriptional factors can also be achieved, but spontaneous integration prohibits these methods from any clinical-grade application. Tuning DAn cell type is achieved with the addition of the WNT signaling molecule CHIR99021 (CHIR). The more CHIR added, the more hindbrain characteristics DA neurons adopt [71]. With the correct amount, DAns of the SNpc can be achieved that express characteristic GIRK2 markers.

Neurogenesis of localized DAns in iPSC lines provides unparalleled modeling of human conditions in PD. In stem cell models, unlike other model organisms, endogenous cellular machinery and transcriptional feedback are preserved, a fundamental step in accurately modeling this genetically complex disease. iPSCs have also been used to model AD, suggesting broader applications to a whole 
range of neurodegenerative disorders [72]. Furthermore, iPSC lines can now be maintained with a natural susceptibility to PD pathology without unnaturally high oxidation from MPTP. Genetic effects may be further isolated by the implementation of CRISPR/Cas9 editing to reduce genetic and clonal variation. iPSC mutation models can be additionally genetically corrected at dedifferentiation and co-cultured with mutant lines to control for epigenetic and passage state [73]. Though reprogramming technologies have been used on patients with idiopathic PD, an iPSC model offers the greatest genetic insight into patients with monogenetic causes.

In 2011, the first iPSC line with genetically linked PD was established with an A53T mutation in the SNCA gene [74]. The mutation was subsequently fixed and both mutant and edited cell lines were co-differentiated to tyrosine hydroxylase positive $(\mathrm{TH}+)$ neurons. Dozens of lines have also been taken from members of the Iowa kindred with duplications and triplications of the SNCA gene [75]. These lines have shown increased sensitivity to neurotoxins and oxidative stressors, indicating a more accurate model of PD, but with healthy skepticism as the addition of toxins may not accurately portray the underlying mechanisms of PD [52]. Nevertheless, these models are useful in exploring affected patients' endogenous response to environmental damage, possibly indicating mitochondrial malfunction. While this list is in no way exhaustive, genetic susceptibility has also been quantified in multiple iPSC lines with LRRK2 [76-78], PINK1 [79] and GBA mutations [80]. Perhaps iPSC technology will also be used as a diagnostic tool in the future to predict individual susceptibility to PD as well as a sourcing cell therapy.

The predisposition of DAn death in the ventral midbrain had long eluded models, but a new generation of iPSC mutant lines meets the challenge. Additionally, iPSC lines are established without the sacrifice of human zygotes or damaging side-effects in drug trials, allowing for the investigation of pathology without human harm or ethical concerns. These conditions are all foundational to two treatments only now within reach: cell therapy and patient-specific transplantation.

\section{7. iPSCs as Cell Therapy for Parkinson's Disease}

Initial treatment of PD started in 1960 with the discovery that affected individuals lacked neurological dopamine. Clinicians began administering intravenous L-Dopa with almost immediate improvement of symptoms [81]. L-Dopa treatment remained the gold standard of treating PD for decades, but currently, there are other commercially available medications that target PD without a dopaminergic mechanism of action [82]. This increased focus on the dopaminergic pathway also helped in illuminating the motor circuitry of the basal ganglia by increasing funding to understand the broader interplay of PD's pathophysiology. With a new understanding of the affected circuits, deep brain stimulation (DBS) by electrical stimulation to the internal segment of the globus pallidus and subthalamic nucleus was introduced as a supplemental therapy with dramatically positive results [83]. Time in the field of DBS has only improved the precision of electrode placement, higher flexibility and longer battery life to curb side-effects [83-85]. Like most neurological disorders, a number of studies have also shown the relative effectiveness of non-medical, non-surgical interventions such as exercise, dance and meditation [86,87].

Sparked by the genetic revolution, revealed subcellular mechanisms finally allow for a shift in focus from symptomatic therapies to the development of clinical-grade, disease-modifying treatment. Not for lack of interest, no disease-altering therapeutic options are currently available that can slow or halt the neurodegeneration of PD. However, there are a handful of drug candidates that show promise in varying stages of clinical trials for both general and sub-populations [88]. Such drugs include the LRRK2 inhibitor DNL201 in Phase I and the general dopamine agonist of dopaminergic D1 receptors PF-06412562 now in Phase III of clinical trials [36,89]. As noted above, clinicians are beginning to target the dysfunction of the specific biochemical pathways leading to PD using precision medicine.

The effectiveness of iPSCs has also been examined as a method to achieve such disease-altering treatment. Stem cells have already been used as therapy in a number of trials involving neural damage. The first occurred in 2010 with a clinical trial that used hESCs to treat spinal cord injury (SCI) [90]. 
Since then, stem cell-derived products have been used in other animal and human trials for therapy of neural disorders ranging from positive results with age-related macular degeneration (AMD) to poor results in AD [91,92]. These trials produced mixed results-in some cases highlighting the limitations of model organisms, due to cellular and gross anatomical differences, to predict the efficacy of treatment in human neurodegeneration [93].

With relatively localized neurodegeneration, PD is also a good candidate for cell therapy. Fetal tissue of the ventral midbrain was implanted in PD patients in 1987, and results from the trial showed cell survival and DAn functionality even 20 years after implantation in some cases [94,95]. As discussed above, the ethics of harvesting 4-10 embryos per patient and limitations to cell survival after preservation prevents fetal cell grafts as a viable form of cellular therapy on a national scale [96]. hESCs are also being utilized in a 2017 Chinese trial for PD, but it is too early to speculate on its effectiveness without conclusive data [97]. Though hESC implantation may produce promising results, strong immunosuppressants must be used to ensure that the graft is accepted. Safety in transplantation of all reprogrammed cells is paramount. Precautions must be taken to prevent infection, graft-induced dyskinesia and tumorigenesis when transplantation trials are conducted. Though cellular transplantation always poses some risk, the advantages of iPSCs present a viable future for cell therapy of PD. The history of these pertinent cell-based therapies can be visualized in Figure 2.

\section{Cell Therapies in Clinical Trials}

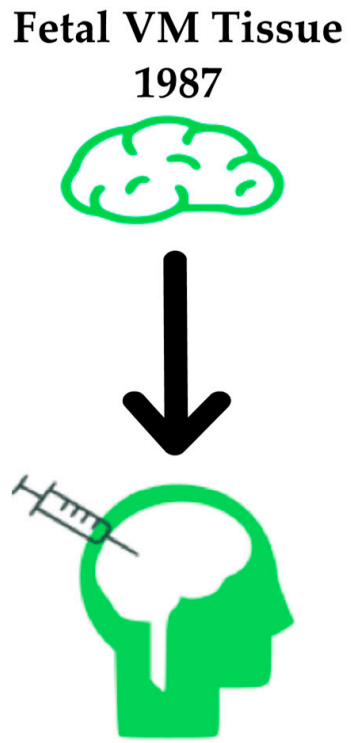

PD

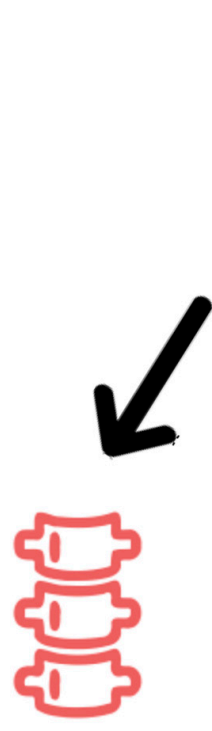

SCI
hESCs 2010-2018
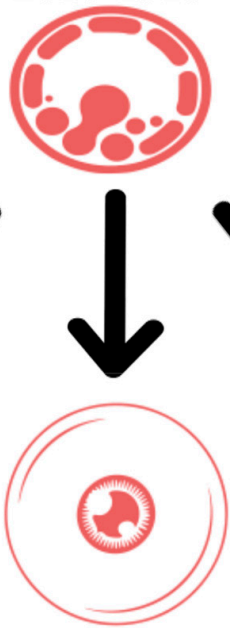

AMD Cardiomyocyte Death
iPSCs 2018
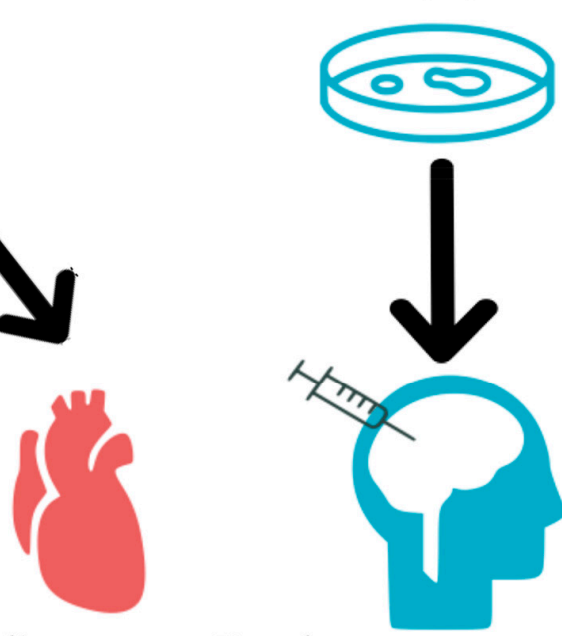

PD

Figure 2. The progression of pluripotent cell-based therapies within the context of Parkinson's Disease (PD) research. Beginning in 1987, fetal ventral midbrain (VM) tissue used as the cell source for the first clinical trial using cells to treat PD. In recent years, human embryonic stem cells (hESCs) are being utilized in a number of clinical trials involving neurodegeneration. Use of hESCs has shown special promise in spinal cord injury (SCI), age-related macular degeneration (AMD) as well as cell damage to the heart. In the summer of 2018, clinicians are beginning to undertake the first human trial using induced pluripotent stem cells (iPSCs) as a cell source to treat PD [57]. This trial will follow seven patients over the course of two years. The outcomes of these trials are detailed in the text.

The first advantage is that iPSC lines can be established without the sacrifice of human embryos, removing a large ethical obstacle of human stem cell treatments. iPSCs also permit human leukocyte antigen (HLA) matches in patient-specific treatments, effectively reducing the severity of post-operational immunosuppressants. Histocompatibility has additionally shown a reduced immune 
response of lymphocytes and microglia as well as increased cell survival in iPSC transplantation of DAns in primate studies [98]. iPS dedifferentiation and reprogramming may be lengthy and burden the patient with high cost but reduced immune rejection and generic donor lines could significantly reduce costs when scaled up. The steps required for patient-specific transplantation of iPSCs are outlined in Figure 3. In Japan, researchers estimate that 50 iPS lines from HLA-homozygous donors will cover $73 \%$ of the Japanese population by matching three HLA loci (A, B and DR) [62]. Primate studies have already demonstrated significant improvements two years after transplanting human iPSCs into the non-human primate model of PD [99]. These human iPSC transplants into non-human primates functioned as midbrain DAns with improvement in scored movement. Similarly, postmortem analyses of iPSC transplants in non-human primate models reveal robust growth, proliferation and integration into existing neural networks $[99,100]$. Primate transplantation has also been achieved with clinical grade human ESCs and showed no significant tumor formation, as well as significant recovery of movement [101]. Clinical efficacy of treating PD with iPSC grafts in humans, however, will be established in the approaching future.
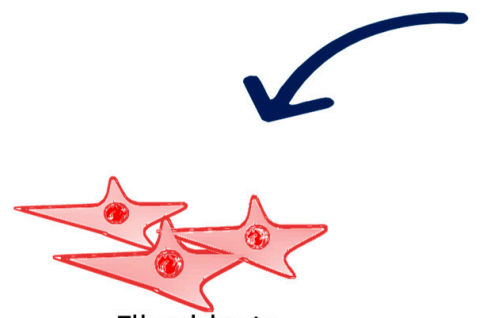

Fibroblasts
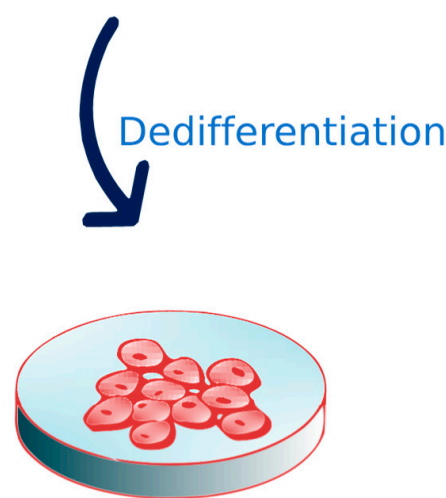

Mutant iPSC Line

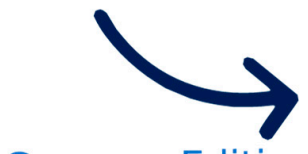

Genome Editing
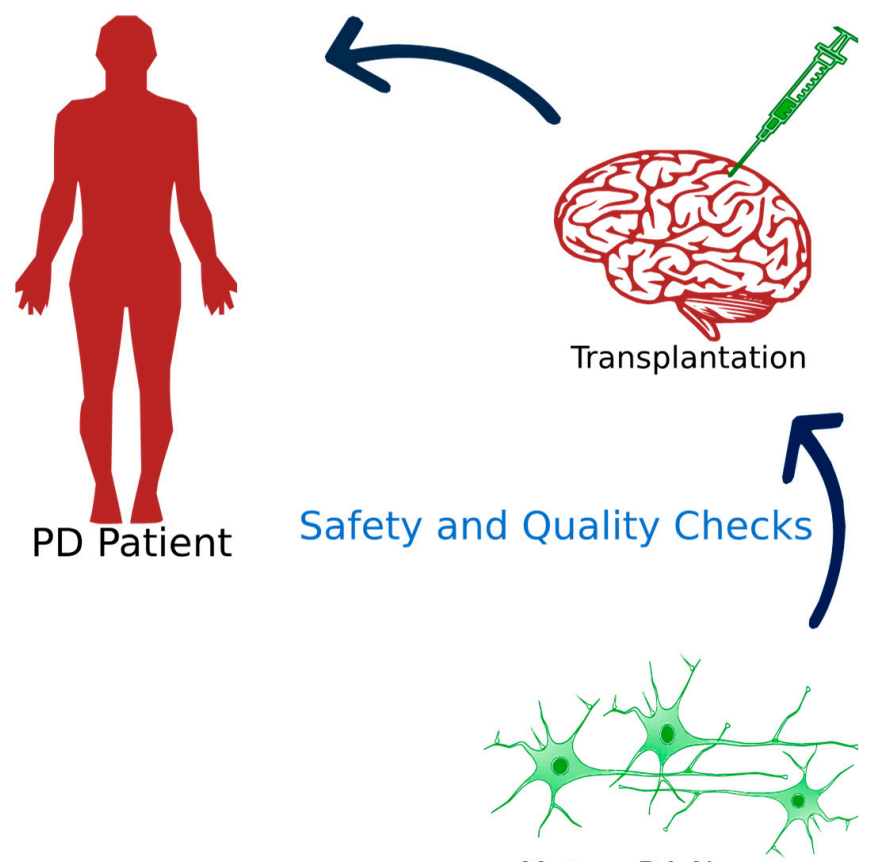

Mature DA Neurons

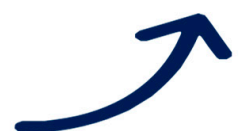

Differentiation

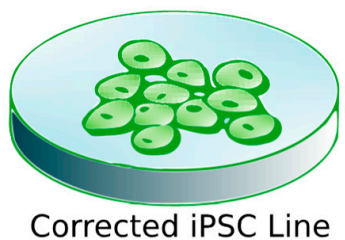

Figure 3. iPSC transplantation. First, fibroblasts are obtained from a patient afflicted with familial PD. Researchers express major reprogramming transcription factors to establish a mutant iPSC line. Using ZNF/TALEN or CRISPR/Cas9 technology, the significant mutation is corrected and then the line is differentiated into mature or progenitor DA neurons in xeno-free conditions. After sufficient quality assurance, the differentiated cells can then be used for clinical trials.

The primary difference between primate and human studies will be the treatment of actual PD patients as opposed to chemically-induced primate models. A team headed by Takahashi announced the first human clinical trial of iPSC-generated DAn transplantation to treat PD [102]. The trial began August 1st, 2018 at Kyoto University Hospital [57]. Cells will be sourced from third-party donors 
with matching HLA loci to ensure genetic integrity and eliminate the patients' genetic interference. Additional testing was performed in rat models to confirm efficacy [103]. However, patients will still receive immunosuppressants due to the trial's exploratory nature. Approximately 5 million cells will be administered to the SNpc through two drilled holes in the skull [104]. Seven patients with moderate PD have been selected for the trial with the benefit of cell therapy earlier on in neurodegeneration but also posing greater experimental risks and will be followed for two years. Clinicians will monitor the progression of the disease, as well as other side effects of too much dopamine in the SNpc that would result in involuntary movements. While many questions and ethical issues surrounding iPSCs and genetic engineering remain, the future for PD looks promising. However, iPSC treatment of PD will likely not completely restore function and should be examined within the context of other treatment options.

\section{Conclusions}

The loss of even a small cluster of 7800 DAns in the SNpc may result in severe debilitation in PD patients. Though cell death may arise from a number of postulated mechanisms, ultimately neuron survival is integral for proper motor and cognitive function. With no current therapies to recover from critical cell death, iPSCs provide an alternate route to potentially restore a disease-free state. Instead, patient-specific cells that are not predisposed to PD may be transplanted back into the SNpc, an ambition to restore function finally within reach. Programmed cell death does not afflict PD patients alone. However, iPSC therapies are better suited for PD as opposed to other forms of neurodegeneration because PD neuronal death is relatively localized. Cell therapies can, therefore, be targeted and less invasive than would be required to combat more diffuse and extensive degeneration such as ALS or AD. As has been previously shown in animal and primate models, patient-specific cell therapies, in combination with personalized pharmacogenetics, may offer the way forward to mitigating PD's crippling form of neurodegeneration in humans.

Funding: This research received no external funding.

Acknowledgments: The Mallett Family for support of this research.

Conflicts of Interest: The authors declare no conflict of interest.

\section{References}

1. De Lau, L.M.; Breteler, M.M. Epidemiology of Parkinson's disease. Lancet Neurol. 2006, 5, 525-535. [CrossRef]

2. Samii, A.; Nutt, J.G.; Ransom, B.R. Parkinson's disease. Lancet 2004, 363, 1783-1793. [CrossRef]

3. Lees, A.J.; Hardy, J.; Revesz, T. Parkinson's disease. Lancet 2009, 373, 2055-2066. [CrossRef]

4. Hughes, A.J.; Daniel, S.E.; Kilford, L.; Lees, A.J. Accuracy of clinical diagnosis of idiopathic Parkinson's disease: A clinico-pathological study of 100 cases. J. Neurol. Neurosurg. Psychiatry 1992, 55, 181-184. [CrossRef] [PubMed]

5. Langston, J.W. The Parkinson's complex: Parkinsonism is just the tip of the iceberg. Ann. Neurol. 2006, 59, 591-596. [CrossRef] [PubMed]

6. Wakabayashi, K.; Takahashi, H. Neuropathology of autonomic nervous system in Parkinson's disease. Eur. Neurol. 1997, 38 (Suppl. 2), 2-7. [CrossRef]

7. Liu, A.K.; Chang, R.C.; Pearce, R.K.; Gentleman, S.M. Nucleus basalis of Meynert revisited: Anatomy, history and differential involvement in Alzheimer's and Parkinson's disease. Acta Neuropathol. 2015, 129, 527-540. [CrossRef]

8. Kahle, P.J.; Neumann, M.; Ozmen, L.; Muller, V.; Jacobsen, H.; Schindzielorz, A.; Okochi, M.; Leimer, U.; van Der Putten, H.; Probst, A.; et al. Subcellular localization of wild-type and Parkinson's disease-associated mutant alpha -synuclein in human and transgenic mouse brain. J. Neurosci. 2000, 20, 6365-6373. [CrossRef]

9. Nemani, V.M.; Lu, W.; Berge, V.; Nakamura, K.; Onoa, B.; Lee, M.K.; Chaudhry, F.A.; Nicoll, R.A.; Edwards, R.H. Increased expression of alpha-synuclein reduces neurotransmitter release by inhibiting synaptic vesicle reclustering after endocytosis. Neuron 2010, 65, 66-79. [CrossRef] 
10. Bartels, T.; Choi, J.G.; Selkoe, D.J. alpha-Synuclein occurs physiologically as a helically folded tetramer that resists aggregation. Nature 2011, 477, 107-110. [CrossRef]

11. Braak, H.; Del Tredici, K.; Rub, U.; de Vos, R.A.; Jansen Steur, E.N.; Braak, E. Staging of brain pathology related to sporadic Parkinson's disease. Neurobiol. Aging 2003, 24, 197-211. [CrossRef]

12. Martinez-Fernandez, R.; Schmitt, E.; Martinez-Martin, P.; Krack, P. The hidden sister of motor fluctuations in Parkinson's disease: A review on nonmotor fluctuations. Mov. Disord. 2016, 31, 1080-1094. [CrossRef] [PubMed]

13. Tolosa, E.; Wenning, G.; Poewe, W. The diagnosis of Parkinson's disease. Lancet Neurol. 2006, 5, 75-86. [CrossRef]

14. Ferreira, M.; Massano, J. An updated review of Parkinson's disease genetics and clinicopathological correlations. Acta Neurol. Scand. 2017, 135, 273-284. [CrossRef] [PubMed]

15. Milosevic, J.; Schwarz, S.C.; Ogunlade, V.; Meyer, A.K.; Storch, A.; Schwarz, J. Emerging role of LRRK2 in human neural progenitor cell cycle progression, survival and differentiation. Mol. Neurodegener. 2009, 4, 25. [CrossRef] [PubMed]

16. Polymeropoulos, M.H.; Lavedan, C.; Leroy, E.; Ide, S.E.; Dehejia, A.; Dutra, A.; Pike, B.; Root, H.; Rubenstein, J.; Boyer, R.; et al. Mutation in the alpha-synuclein gene identified in families with Parkinson's disease. Science 1997, 276, 2045-2047. [CrossRef] [PubMed]

17. Singh Dolt, K.; Hammachi, F.; Kunath, T. Modeling Parkinson's disease with induced pluripotent stem cells harboring alpha-synuclein mutations. Brain Pathol. 2017, 27, 545-551. [CrossRef]

18. Savica, R.; Grossardt, B.R.; Bower, J.H.; Ahlskog, J.E.; Rocca, W.A. Time Trends in the Incidence of Parkinson Disease. JAMA Neurol. 2016, 73, 981-989. [CrossRef]

19. Singleton, A.B.; Farrer, M.; Johnson, J.; Singleton, A.; Hague, S.; Kachergus, J.; Hulihan, M.; Peuralinna, T.; Dutra, A.; Nussbaum, R.; et al. alpha-Synuclein locus triplication causes Parkinson's disease. Science 2003, 302, 841. [CrossRef]

20. Funayama, M.; Hasegawa, K.; Kowa, H.; Saito, M.; Tsuji, S.; Obata, F. A new locus for Parkinson's disease (PARK8) maps to chromosome 12p11.2-q13.1. Ann. Neurol. 2002, 51, 296-301. [CrossRef]

21. Paisan-Ruiz, C.; Jain, S.; Evans, E.W.; Gilks, W.P.; Simon, J.; van der Brug, M.; Lopez de Munain, A.; Aparicio, S.; Gil, A.M.; Khan, N.; et al. Cloning of the gene containing mutations that cause PARK8-linked Parkinson's disease. Neuron 2004, 44, 595-600. [CrossRef] [PubMed]

22. Hasegawa, K.; Stoessl, A.J.; Yokoyama, T.; Kowa, H.; Wszolek, Z.K.; Yagishita, S. Familial parkinsonism: Study of original sagamihara PARK8 (I2020T) kindred with variable clinicopathologic outcomes. Park. Relat. Disord. 2009, 15, 300-306. [CrossRef] [PubMed]

23. Zimprich, A.; Biskup, S.; Leitner, P.; Lichtner, P.; Farrer, M.; Lincoln, S.; Kachergus, J.; Hulihan, M.; Uitti, R.J.; Calne, D.B.; et al. Mutations in LRRK2 cause autosomal-dominant parkinsonism with pleomorphic pathology. Neuron 2004, 44, 601-607. [CrossRef] [PubMed]

24. Healy, D.G.; Falchi, M.; O’Sullivan, S.S.; Bonifati, V.; Durr, A.; Bressman, S.; Brice, A.; Aasly, J.; Zabetian, C.P.; Goldwurm, S.; et al. Phenotype, genotype, and worldwide genetic penetrance of LRRK2-associated Parkinson's disease: A case-control study. Lancet Neurol. 2008, 7, 583-590. [CrossRef]

25. Heo, H.Y.; Park, J.M.; Kim, C.H.; Han, B.S.; Kim, K.S.; Seol, W. LRRK2 enhances oxidative stress-induced neurotoxicity via its kinase activity. Exp. Cell Res. 2010, 316, 649-656. [CrossRef] [PubMed]

26. West, A.B.; Moore, D.J.; Biskup, S.; Bugayenko, A.; Smith, W.W.; Ross, C.A.; Dawson, V.L.; Dawson, T.M. Parkinson's disease-associated mutations in leucine-rich repeat kinase 2 augment kinase activity. Proc. Natl. Acad. Sci. USA 2005, 102, 16842-16847. [CrossRef] [PubMed]

27. Abou-Sleiman, P.M.; Healy, D.G.; Quinn, N.; Lees, A.J.; Wood, N.W. The role of pathogenic DJ-1 mutations in Parkinson's disease. Ann. Neurol. 2003, 54, 283-286. [CrossRef] [PubMed]

28. Kumazawa, R.; Tomiyama, H.; Li, Y.; Imamichi, Y.; Funayama, M.; Yoshino, H.; Yokochi, F.; Fukusako, T.; Takehisa, Y.; Kashihara, K.; et al. Mutation analysis of the PINK1 gene in 391 patients with Parkinson disease. Arch. Neurol. 2008, 65, 802-808. [CrossRef]

29. Anheim, M.; Elbaz, A.; Lesage, S.; Durr, A.; Condroyer, C.; Viallet, F.; Pollak, P.; Bonaiti, B.; Bonaiti-Pellie, C.; Brice, A. Penetrance of Parkinson disease in glucocerebrosidase gene mutation carriers. Neurology 2012, 78, 417-420. [CrossRef]

30. Sidransky, E.; Nalls, M.A.; Aasly, J.O.; Aharon-Peretz, J.; Annesi, G.; Barbosa, E.R.; Bar-Shira, A.; Berg, D.; Bras, J.; Brice, A.; et al. Multicenter analysis of glucocerebrosidase mutations in Parkinson's disease. N. Engl. J. Med. 2009, 361, 1651-1661. [CrossRef] 
31. Titova, N.; Chaudhuri, K.R. Personalized medicine in Parkinson's disease: Time to be precise. Mov. Disord. 2017, 32, 1147-1154. [CrossRef] [PubMed]

32. Jellinger, K.A. Neuropathobiology of non-motor symptoms in Parkinson disease. J. Neural Transm. 2015, 122, 1429-1440. [CrossRef] [PubMed]

33. Jimenez-Jimenez, F.J.; Alonso-Navarro, H.; Garcia-Martin, E.; Agundez, J.A. Advances in understanding genomic markers and pharmacogenetics of Parkinson's disease. Expert Opin. Drug Metab. Toxicol. 2016, 12, 433-448. [CrossRef] [PubMed]

34. Kim, H.J.; Jeon, B. How close are we to individualized medicine for Parkinson's disease? Expert Rev. Neurother. 2016, 16, 815-830. [CrossRef] [PubMed]

35. Taymans, J.M.; Greggio, E. LRRK2 kinase inhibition as a therapeutic strategy for Parkinson's disease, where do we stand? Curr. Neuropharmacol. 2016, 14, 214-225. [CrossRef] [PubMed]

36. Therapeutics, D. Available online: http://investors.denalitherapeutics.com/news-releases/news-releasedetails/denali-therapeutics-announces-positive-clinical-results-lrrk2\#ir-pages (accessed on 26 October 2018).

37. Cacabelos, R. Parkinson's Disease: From Pathogenesis to Pharmacogenomics. Int. J. Mol. Sci. 2017, $18,551$. [CrossRef] [PubMed]

38. Zappia, M.; Annesi, G.; Nicoletti, G.; Arabia, G.; Annesi, F.; Messina, D.; Pugliese, P.; Spadafora, P.; Tarantino, P.; Carrideo, S.; et al. Sex differences in clinical and genetic determinants of levodopa peak-dose dyskinesias in Parkinson disease: An exploratory study. Arch. Neurol. 2005, 62, 601-605. [CrossRef] [PubMed]

39. Vernon, A.C.; Ballard, C.; Modo, M. Neuroimaging for Lewy body disease: Is the in vivo molecular imaging of alpha-synuclein neuropathology required and feasible? Brain Res. Rev. 2010, 65, 28-55. [CrossRef]

40. Zhang, X.; Jin, H.; Padakanti, P.K.; Li, J.; Yang, H.; Fan, J.; Mach, R.H.; Kotzbauer, P.; Tu, Z. Radiosynthesis and in vivo evaluation of two PET radioligands for imaging alpha-synuclein. Appl. Sci. 2014, 4, 66-78. [CrossRef]

41. Bagchi, D.P.; Yu, L.; Perlmutter, J.S.; Xu, J.; Mach, R.H.; Tu, Z.; Kotzbauer, P.T. Binding of the radioligand SIL23 to alpha-synuclein fibrils in Parkinson disease brain tissue establishes feasibility and screening approaches for developing a Parkinson disease imaging agent. PLoS ONE 2013, 8, e55031. [CrossRef]

42. Weintraub, D.; Claassen, D.O. Impulse control and related disorders in Parkinson's disease. Int. Rev. Neurobiol. 2017, 133, 679-717. [CrossRef] [PubMed]

43. Masliah, E.; Rockenstein, E.; Veinbergs, I.; Mallory, M.; Hashimoto, M.; Takeda, A.; Sagara, Y.; Sisk, A.; Mucke, L. Dopaminergic loss and inclusion body formation in alpha-synuclein mice: Implications for neurodegenerative disorders. Science 2000, 287, 1265-1269. [CrossRef] [PubMed]

44. Van der Putten, H.; Wiederhold, K.H.; Probst, A.; Barbieri, S.; Mistl, C.; Danner, S.; Kauffmann, S.; Hofele, K.; Spooren, W.P.; Ruegg, M.A.; et al. Neuropathology in mice expressing human alpha-synuclein. J. Neurosci. 2000, 20, 6021-6029. [CrossRef] [PubMed]

45. Greene, J.C.; Whitworth, A.J.; Kuo, I.; Andrews, L.A.; Feany, M.B.; Pallanck, L.J. Mitochondrial pathology and apoptotic muscle degeneration in Drosophila parkin mutants. Proc. Natl. Acad. Sci. USA 2003, 100, 4078-4083. [CrossRef]

46. Bezard, E.; Jaber, M.; Gonon, F.; Boireau, A.; Bloch, B.; Gross, C.E. Adaptive changes in the nigrostriatal pathway in response to increased 1-methyl-4-phenyl-1,2,3,6-tetrahydropyridine-induced neurodegeneration in the mouse. Eur. J. Neurosci. 2000, 12, 2892-2900. [CrossRef]

47. Chen, M.K.; Kuwabara, H.; Zhou, Y.; Adams, R.J.; Brasic, J.R.; McGlothan, J.L.; Verina, T.; Burton, N.C.; Alexander, M.; Kumar, A.; et al. VMAT2 and dopamine neuron loss in a primate model of Parkinson's disease. J. Neurochem. 2008, 105, 78-90. [CrossRef] [PubMed]

48. Chen, Z. Cell therapy for Parkinson's disease: New hope from reprogramming technologies. Aging Dis. 2015, 6, 499-503. [CrossRef] [PubMed]

49. Di Monte, D.A.; McCormack, A.; Petzinger, G.; Janson, A.M.; Quik, M.; Langston, W.J. Relationship among nigrostriatal denervation, parkinsonism, and dyskinesias in the MPTP primate model. Mov. Disord. 2000, 15, 459-466. [CrossRef]

50. Mikkelsen, M.; Moller, A.; Jensen, L.H.; Pedersen, A.; Harajehi, J.B.; Pakkenberg, H. MPTP-induced Parkinsonism in minipigs: A behavioral, biochemical, and histological study. Neurotoxicol. Teratol. 1999, 21, 169-175. [CrossRef] 
51. Schneider, J.S.; Schroeder, J.A.; Rothblat, D.S. Differential recovery of sensorimotor function in GM1 ganglioside-treated vs. spontaneously recovered MPTP-treated cats: Partial striatal dopaminergic reinnervation vs. neurochemical compensation. Brain Res. 1998, 813, 82-87. [CrossRef]

52. Byers, B.; Lee, H.L.; Reijo Pera, R. Modeling Parkinson's disease using induced pluripotent stem cells. Curr. Neurol. Neurosci. Rep. 2012, 12, 237-242. [CrossRef] [PubMed]

53. Nashun, B.; Hill, P.W.; Hajkova, P. Reprogramming of cell fate: Epigenetic memory and the erasure of memories past. EMBO J. 2015, 34, 1296-1308. [CrossRef] [PubMed]

54. Phetfong, J.; Supokawej, A.; Wattanapanitch, M.; Kheolamai, P.; U-pratya, Y.; Issaragrisil, S. Cell type of origin influences iPSC generation and differentiation to cells of the hematoendothelial lineage. Cell Tissue Res. 2016, 365, 101-112. [CrossRef] [PubMed]

55. Ruetz, T.; Kaji, K. Routes to induced pluripotent stem cells. Curr. Opin. Genet. Dev. 2014, 28, 38-42. [CrossRef] [PubMed]

56. Takahashi, K.; Yamanaka, S. A decade of transcription factor-mediated reprogramming to pluripotency. Nat. Rev. Mol. Cell Biol. 2016, 17, 183-193. [CrossRef] [PubMed]

57. UMIN. Kyoto Trial to Evaluate the Safety and Efficacy of iPSC-Derived Dopaminergic Progenitors in the Treatment of Parkinson's Disease. Available online: https:/ / upload.umin.ac.jp/cgi-open-bin/ctr_e/ctr_ view.cgi?recptno=R000038278 (accessed on 21 December 2018).

58. Takahashi, J. Stem cells and regenerative medicine for neural repair. Curr. Opin. Biotechnol. 2018, 52, $102-108$. [CrossRef] [PubMed]

59. Takahashi, K.; Yamanaka, S. Induction of pluripotent stem cells from mouse embryonic and adult fibroblast cultures by defined factors. Cell 2006, 126, 663-676. [CrossRef]

60. Playne, R.; Connor, B. Understanding Parkinson's disease through the use of cell reprogramming. Stem Cell Rev. 2017, 13, 151-169. [CrossRef]

61. Fusaki, N.; Ban, H.; Nishiyama, A.; Saeki, K.; Hasegawa, M. Efficient induction of transgene-free human pluripotent stem cells using a vector based on Sendai virus, an RNA virus that does not integrate into the host genome. Proc. Jpn. Acad. 2009, 85, 348-362. [CrossRef]

62. Okita, K.; Matsumura, Y.; Sato, Y.; Okada, A.; Morizane, A.; Okamoto, S.; Hong, H.; Nakagawa, M.; Tanabe, K.; Tezuka, K.; et al. A more efficient method to generate integration-free human iPS cells. Nat. Methods 2011, 8, 409-412. [CrossRef]

63. Warren, L.; Manos, P.D.; Ahfeldt, T.; Loh, Y.H.; Li, H.; Lau, F.; Ebina, W.; Mandal, P.K.; Smith, Z.D.; Meissner, A.; et al. Highly efficient reprogramming to pluripotency and directed differentiation of human cells with synthetic modified mRNA. Cell Stem Cell 2010, 7, 618-630. [CrossRef] [PubMed]

64. Gore, A.; Li, Z.; Fung, H.L.; Young, J.E.; Agarwal, S.; Antosiewicz-Bourget, J.; Canto, I.; Giorgetti, A.; Israel, M.A.; Kiskinis, E.; et al. Somatic coding mutations in human induced pluripotent stem cells. Nature 2011, 471, 63-67. [CrossRef] [PubMed]

65. Muller, F.J.; Schuldt, B.M.; Williams, R.; Mason, D.; Altun, G.; Papapetrou, E.P.; Danner, S.; Goldmann, J.E.; Herbst, A.; Schmidt, N.O.; et al. A bioinformatic assay for pluripotency in human cells. Nat. Methods 2011, 8, 315-317. [CrossRef] [PubMed]

66. Ono, Y.; Nakatani, T.; Sakamoto, Y.; Mizuhara, E.; Minaki, Y.; Kumai, M.; Hamaguchi, A.; Nishimura, M.; Inoue, Y.; Hayashi, H.; et al. Differences in neurogenic potential in floor plate cells along an anteroposterior location: Midbrain dopaminergic neurons originate from mesencephalic floor plate cells. Development 2007, 134, 3213-3225. [CrossRef] [PubMed]

67. Kriks, S.; Shim, J.W.; Piao, J.; Ganat, Y.M.; Wakeman, D.R.; Xie, Z.; Carrillo-Reid, L.; Auyeung, G.; Antonacci, C.; Buch, A.; et al. Dopamine neurons derived from human ES cells efficiently engraft in animal models of Parkinson's disease. Nature 2011, 480, 547-551. [CrossRef] [PubMed]

68. Bonilla, S.; Hall, A.C.; Pinto, L.; Attardo, A.; Gotz, M.; Huttner, W.B.; Arenas, E. Identification of midbrain floor plate radial glia-like cells as dopaminergic progenitors. GLIA 2008, 56, 809-820. [CrossRef]

69. Fasano, C.A.; Chambers, S.M.; Lee, G.; Tomishima, M.J.; Studer, L. Efficient derivation of functional floor plate tissue from human embryonic stem cells. Cell Stem Cell 2010, 6, 336-347. [CrossRef]

70. Ye, W.; Shimamura, K.; Rubenstein, J.L.; Hynes, M.A.; Rosenthal, A. FGF and Shh signals control dopaminergic and serotonergic cell fate in the anterior neural plate. Cell 1998, 93, 755-766. [CrossRef] 
71. Kirkeby, A.; Grealish, S.; Wolf, D.A.; Nelander, J.; Wood, J.; Lundblad, M.; Lindvall, O.; Parmar, M. Generation of regionally specified neural progenitors and functional neurons from human embryonic stem cells under defined conditions. Cell Rep. 2012, 1, 703-714. [CrossRef]

72. Israel, M.A.; Yuan, S.H.; Bardy, C.; Reyna, S.M.; Mu, Y.; Herrera, C.; Hefferan, M.P.; Van Gorp, S.; Nazor, K.L.; Boscolo, F.S.; et al. Probing sporadic and familial Alzheimer's disease using induced pluripotent stem cells. Nature 2012, 482, 216-220. [CrossRef]

73. Howden, S.E.; Maufort, J.P.; Duffin, B.M.; Elefanty, A.G.; Stanley, E.G.; Thomson, J.A. Simultaneous reprogramming and gene correction of patient fibroblasts. Stem Cell Rep. 2015, 5, 1109-1118. [CrossRef] [PubMed]

74. Soldner, F.; Laganiere, J.; Cheng, A.W.; Hockemeyer, D.; Gao, Q.; Alagappan, R.; Khurana, V.; Golbe, L.I.; Myers, R.H.; Lindquist, S.; et al. Generation of isogenic pluripotent stem cells differing exclusively at two early onset Parkinson point mutations. Cell 2011, 146, 318-331. [CrossRef] [PubMed]

75. Devine, M.J.; Ryten, M.; Vodicka, P.; Thomson, A.J.; Burdon, T.; Houlden, H.; Cavaleri, F.; Nagano, M.; Drummond, N.J.; Taanman, J.W.; et al. Parkinson's disease induced pluripotent stem cells with triplication of the alpha-synuclein locus. Nat. Commun. 2011, 2, 440. [CrossRef] [PubMed]

76. Nguyen, H.N.; Byers, B.; Cord, B.; Shcheglovitov, A.; Byrne, J.; Gujar, P.; Kee, K.; Schule, B.; Dolmetsch, R.E.; Langston, W.; et al. LRRK2 mutant iPSC-derived DA neurons demonstrate increased susceptibility to oxidative stress. Cell Stem Cell 2011, 8, 267-280. [CrossRef] [PubMed]

77. Reinhardt, P.; Schmid, B.; Burbulla, L.F.; Schondorf, D.C.; Wagner, L.; Glatza, M.; Hoing, S.; Hargus, G.; Heck, S.A.; Dhingra, A.; et al. Genetic correction of a LRRK2 mutation in human iPSCs links parkinsonian neurodegeneration to ERK-dependent changes in gene expression. Cell Stem Cell 2013, 12, 354-367. [CrossRef] [PubMed]

78. Sanders, L.H.; Laganiere, J.; Cooper, O.; Mak, S.K.; Vu, B.J.; Huang, Y.A.; Paschon, D.E.; Vangipuram, M.; Sundararajan, R.; Urnov, F.D.; et al. LRRK2 mutations cause mitochondrial DNA damage in iPSC-derived neural cells from Parkinson's disease patients: Reversal by gene correction. Neurobiol. Dis. 2014, 62, 381-386. [CrossRef] [PubMed]

79. Cooper, O.; Astradsson, A.; Hallett, P.; Robertson, H.; Mendez, I.; Isacson, O. Lack of functional relevance of isolated cell damage in transplants of Parkinson's disease patients. J. Neurol. 2009, 256 (Suppl. 3), 310-316. [CrossRef]

80. Schondorf, D.C.; Aureli, M.; McAllister, F.E.; Hindley, C.J.; Mayer, F.; Schmid, B.; Sardi, S.P.; Valsecchi, M.; Hoffmann, S.; Schwarz, L.K.; et al. iPSC-derived neurons from GBA1-associated Parkinson's disease patients show autophagic defects and impaired calcium homeostasis. Nat. Commun. 2014, 5, 4028. [CrossRef]

81. Birkmayer, W.; Hornykiewicz, O. The L-3,4-dioxyphenylalanine (DOPA)-effect in Parkinson-akinesia. Wien. Klin. Wochenschr. 1961, 73, 787-788. (In German)

82. Oertel, W.H. Recent advances in treating Parkinson's disease. F1000Research 2017, 6, 260. [CrossRef]

83. McIntyre, C.C.; Anderson, R.W. Deep brain stimulation mechanisms: The control of network activity via neurochemistry modulation. J. Neurochem. 2016, 139 (Suppl. 1), 338-345. [CrossRef] [PubMed]

84. Barbe, M.T.; Maarouf, M.; Alesch, F.; Timmermann, L. Multiple source current steering-A novel deep brain stimulation concept for customized programming in a Parkinson's disease patient. Park. Relat. Disord. 2014, 20, 471-473. [CrossRef] [PubMed]

85. Timmermann, L.; Jain, R.; Chen, L.; Maarouf, M.; Barbe, M.T.; Allert, N.; Brucke, T.; Kaiser, I.; Beirer, S.; Sejio, F.; et al. Multiple-source current steering in subthalamic nucleus deep brain stimulation for Parkinson's disease (the VANTAGE study): A non-randomised, prospective, multicentre, open-label study. Lancet Neurol. 2015, 14, 693-701. [CrossRef]

86. Bloem, B.R.; de Vries, N.M.; Ebersbach, G. Nonpharmacological treatments for patients with Parkinson's disease. Mov. Disord. 2015, 30, 1504-1520. [CrossRef]

87. De Vries, N.M.; Sturkenboom, I.H.; Bloem, B.R. Physiotherapy and occupational therapy and mild to moderate Parkinson disease. JAMA Neurol. 2016, 73, 893-894. [CrossRef] [PubMed]

88. Oertel, W.; Schulz, J.B. Current and experimental treatments of Parkinson disease: A guide for neuroscientists. J. Neurochem. 2016, 139 (Suppl. 1), 325-337. [CrossRef]

89. Papapetropoulos, S.; Liu, W.; Duvvuri, S.; Thayer, K.; Gray, D.L. Evaluation of D1/D5 Partial agonist PF-06412562 in Parkinson's disease following oral administration. Neurodegener. Dis. 2018, 18, $262-269$. [CrossRef] 
90. Lebkowski, J. GRNOPC1: The world's first embryonic stem cell-derived therapy. Interview with Jane Lebkowski. Regener. Med. 2011, 6, 11-13. [CrossRef]

91. Mandai, M.; Watanabe, A.; Kurimoto, Y.; Hirami, Y.; Morinaga, C.; Daimon, T.; Fujihara, M.; Akimaru, H.; Sakai, N.; Shibata, Y.; et al. Autologous induced stem-cell-derived retinal cells for macular degeneration. N. Engl. J. Med. 2017, 376, 1038-1046. [CrossRef]

92. Marsh, S.E.; Yeung, S.T.; Torres, M.; Lau, L.; Davis, J.L.; Monuki, E.S.; Poon, W.W.; Blurton-Jones, M. HuCNS-SC human NSCs fail to differentiate, form ectopic clusters, and provide no cognitive benefits in a transgenic model of Alzheimer's disease. Stem Cell Rep. 2017, 8, 235-248. [CrossRef]

93. Lemon, R.N. Descending pathways in motor control. Ann. Rev. Neurosci. 2008, 31, 195-218. [CrossRef] [PubMed]

94. Barker, R.A.; Barrett, J.; Mason, S.L.; Bjorklund, A. Fetal dopaminergic transplantation trials and the future of neural grafting in Parkinson's disease. Lancet Neurol. 2013, 12, 84-91. [CrossRef]

95. Barker, R.A.; Drouin-Ouellet, J.; Parmar, M. Cell-based therapies for Parkinson disease-past insights and future potential. Nat. Rev. Neurol. 2015, 11, 492-503. [CrossRef]

96. Barker, R.A.; Parmar, M.; Studer, L.; Takahashi, J. Human trials of stem cell-derived dopamine neurons for Parkinson's disease: Dawn of a new era. Cell Stem Cell 2017, 21, 569-573. [CrossRef] [PubMed]

97. Cyranoski, D. Trials of embryonic stem cells to launch in China. Nature 2017, 546, 15-16. [CrossRef] [PubMed]

98. Morizane, A.; Kikuchi, T.; Hayashi, T.; Mizuma, H.; Takara, S.; Doi, H.; Mawatari, A.; Glasser, M.F.; Shiina, T.; Ishigaki, H.; et al. MHC matching improves engraftment of iPSC-derived neurons in non-human primates. Nature Commun. 2017, 8, 385. [CrossRef] [PubMed]

99. Kikuchi, T.; Morizane, A.; Doi, D.; Magotani, H.; Onoe, H.; Hayashi, T.; Mizuma, H.; Takara, S.; Takahashi, R.; Inoue, H.; et al. Human iPS cell-derived dopaminergic neurons function in a primate Parkinson's disease model. Nature 2017, 548, 592-596. [CrossRef] [PubMed]

100. Hallett, P.J.; Deleidi, M.; Astradsson, A.; Smith, G.A.; Cooper, O.; Osborn, T.M.; Sundberg, M.; Moore, M.A.; Perez-Torres, E.; Brownell, A.L.; et al. Successful function of autologous iPSC-derived dopamine neurons following transplantation in a non-human primate model of Parkinson's disease. Cell Stem Cell 2015, 16, 269-274. [CrossRef]

101. Wang, Y.K.; Zhu, W.W.; Wu, M.H.; Wu, Y.H.; Liu, Z.X.; Liang, L.M.; Sheng, C.; Hao, J.; Wang, L.; Li, W.; et al. Human clinical-grade parthenogenetic esc-derived dopaminergic neurons recover locomotive defects of nonhuman primate models of Parkinson's disease. Stem Cell Rep. 2018, 11, 171-182. [CrossRef]

102. Announcement of Physician-Initiated Clinical Trials for Parkinson's Disease. Available online: http://www. cira.kyoto-u.ac.jp/e/pressrelease/news/180730-170000.html (accessed on 24 August 2018).

103. Preparing for First Human Trial of iPSC-Derived Cells for Parkinson's Disease: An Interview with Jun Takahashi. Available online: https:/ / www.regmednet.com/users/3641-regmednet/posts/38627-preparingfor-first-human-trial-of-ipsc-derived-cells-for-parkinson-s-disease-an-interview-with-jun-takahashi (accessed on 11 September 2018).

104. First-Of-Its-Kind Clinical Trial Will Use Reprogrammed Adult Stem Cells to Treat Parkinson's. Available online: http://www.sciencemag.org/news/2018/07/first-its-kind-clinical-trial-will-usereprogrammed-adult-stem-cells-treat-parkinson-s (accessed on 21 December 2018).

(C) 2019 by the authors. Licensee MDPI, Basel, Switzerland. This article is an open access article distributed under the terms and conditions of the Creative Commons Attribution (CC BY) license (http://creativecommons.org/licenses/by/4.0/). 